\title{
SIR ISAAC NEWTON
}

Die geweldige oplewing van die Christelike wetenskapsgedagte in ons geeslose tyd, is ongetwyfeld 'n haas onverklaarbare verskynsel. Dwarsdeur die eeue het Christene ook wetenskap beoefen saam met ongelowiges, maar dit was eers in ons leeftyd dat die principia van die Christelike religie ook vrugbaar gemaak is vir die wetenskapsbeoefening. In hierdie verband sal die name van Dooyeweerd, Vollenhoven, Stoker e.a. steeds met eer vermeld word.

Natuurlik het belydende Christene ook voorheen wel deeglik saamgewerk aan die gebou van die wetenskap. Die intieme verband tussen religie, wysbegeerte en wetenskapsbeoefening is toe egter nog nie suiwer ingesien nie. Uit hierdie tydperk dateer die arbeid van sir Isaac Newton.

\section{I}

Rene Descartes, dit word vandag algemeen aanvaar, het 'n revolusie teweeggebring op die gebied van die natuurondersoek. Hy het die natuur beskou as 'n meganisme wat volgens vaste matematiese wette fungeer. Die natuur-ondersoeker moet nie langer vra na die eerste oorsaak nie, maar na die kleinste bestanddele waarin die natuurobjekte opgebreek kan word. Die mens is deel van die natuur; daarom is kennis van sy saamstellende dele van groter belang as metafisiese beskouinge oor sy oorsprong, wese en bestemming. Die mens is deel van die groot onpersoonlike meganisme wat ons die natuur noem.

Op die natuurwetenskappe het Descartes se insigte ' $n$ radikale invloed uitgeoefen. Voordat hierdie nuwe opvattinge oor die mens en die natuur egter ook vrugbaar gemaak kon word vir die empiriese navorsing, moes 'n sielkundige teorie ontwerp word uat berus op die presupposisies van die Cartesiaanse wetenskaplike metode. In hierdie behoefte het John Locke voorsien. In sy Essay concerning human understanding het hy sy teorie van die aangebore ideë ontwikkel wat die weg gebaan het vir die optrede van sir Isaac Newton. Newton is also die man wat die grondlegger geword het van die empiristiese rigting naas die rasionalistiese vleuel van die moderne humanistiese denke. Die matematies-deduktiewe en die empi- 
ries-eksperimentele bewegings in die ontwikkeling van die moderne natuurwetenskappe is in hom verenig.

Die absoluut oorheersende plek wat sir Isaac Newton tot betreklik onlangs in die moderne natuurwetenskaplike denke ingeneem het, kan deur niemand ontken word nie. Sy gesag was onaantasbaar; 'n beroep op Newton was die einde van alle teëspraak. Newton het inderdaad geword wat Aristoteles vir die Oudheid en die Middeleeue was: die onfeilbare outoriteit wie se woord finaal en onbetwisbaar is.

Reeds in sy leeftyd het Newton lof en eer uit alle oorde ingeoes. Hy is gehuldig as iemand wat feitlik "meer as mens" was. Henry Pemberton het bv. getuig dat Newton se optrede onsterflike eer aan die menslike natuur besorg het. Locke het hom die "onvergelyklike Newton" genoem, en sy eie arbeid beskryf as dié van die nederige dienskneg wat sommige van die afval voor Newton se voete verwyder het. Die Engelse digter Pope het 'n versreël opgestel wat as grafskrif bedoel is:

Nature and Nature's laws lay hid in night;

God said: Let Newton be, and all was light.

Elke kind, so skryf George Home, leer feitlik al aan moedersknie dat sir Isaac Newton die filosofie gevoer het tot die allerhoogste top wat denkbaar moontlik is.

Ons glo dat sir Isaac Newton self hierdie onbeteuelde verering sou afgekeur het. Uit sy werke blyk duidelik dat hyself 'n opregte en beskeie denker was. Daarby was hy 'n man van karakter en met 'n diep vrome gemoed. Hy het selfs jare lank 'n groot deel van sy tyd gebruik om 'n kommentaar op die Bybelboek Openbaring gereed te maak. Keer op keer betuig hy ook sy eie onwetendheid en erken hy sy eie beperktheid aan kennis en insig. Dat sy tydgenote en die volgende geslagte soveel onbeperkte lof vir sy werk gehad het, is nie die gevolg van Newton se eie bewuste strewe nie. Hy was afhanklik van sy voorgangers, en hy het hierdie afhanklikheid ook onomwonde erken. Die hulde wat Newton ontvang het, is veeleer die gevolg van die magtige nuwe vergesigte wat hy vir die empiriese natuurvorsing geopen het. Dit het niks minder as ' $n$ omwenteling teweeggebring op tegnologiese en nywerheidsgebied nie. Die hedendaagse beoefening van die natuurwetenskappe kan sonder Newton se aandeel nie begryp of reg beoordeel word nie. Voordat die hedendaagse atoomwondere die wêreld verstom het, was daar geen groter naam op natuurkundige terrein as die naam van sir Isaac Newton nie. 
II

Die uitnemende betekenis van sir Isaac Newton vir die natuurwetenskaplike denke is daarin geleë dat hy die wiskundige en die empiriese aspekte van die Cartesianisme in ' $n$ hegte eenheid verbind het. Enersyds het hy aangesluit by die wiskundige beweging waaraan die name van Copernikus, Kepler en Galileo verbind word; andersyds het hy aanknoping gevind by die empiriese rigting van manne soos Bacon, Gilbert, Harvey en Boyle. Die empiries-eksperimentele en die wiskundig-deduktieue rigtings in die wetenskap vloei ineen by Newton. So het hy die weg help berei vir die industriële en tegnologiese omwentelinge wat die gelaat van die wêreld in die volgende eeue radikaal verander het.

Sir Isaac Newton was ongetwyfeld veeleer 'n briljante natuurwetenskaplike as wat hy 'n sistematiese denker en filosoof was. Tog spreek dit vanself dat sekere deurlopende beginsels ook sy denke beheers het. Wat die metafisiese grondslae van die natuurwetenskaplike denke betref, is die volgende insigte wat ons by hom vind, van belang.

(i) Sy veroordeling van sg. hipoteses: In sy Universal Arithmetic poneer Newton die stelling dat daar probleme is wat eenvoudig nie tot wiskundige terme herlei kan word nie. Hy verwerp m.a.w. die Cartesiaanse apriori, nl. dat die ganse geskape werklikheid wiskundige in struktuur is en alleen deur wiskundige metodes geken kan word. Hy heg nie groot waarde aan denkbeelde en teorieë wat nie berus op eksperimentele navorsing of wat nie d.m.v. eksperimente bewys kan word nie. Vir hom is alleen eksperimentele wette wat deur feite beuys kan word, van belang. As hy soms gebruik maak van hipoteses, dan doen hy groot moeite om hulle baie duidelik te onderskei van resultate wat op waarneming en eksperimente berus. Skynbaar kon hy sy tydgenote nie gewoond maak aan hierdie onderskeiding nie, en derhalwe het hy in later jare doelbewus daarna gestrewe om alle hipoteses uit sy wetenskaplike stelsel te verband. Natuurlik het hy nie volkome hierin geslaag nie. So gee hy bv. in sy Principia die volgende reël: „Dieselfde natuurlike gevolge moet toegeskryf word aan dieselfde natuurlike oorsake".

(ii) Sy verbinding van die wiskundige en empiriese metodes: Hier kan ons Newton se beskouing soos volg saamvat: Die wetenskap bestaan uit wette wat in wiskundige terme 
uitgedruk word en wat baie duidelik afgelei kan word uit die sintuiglik waarneembare dinge en wat eksperimenteel bevestig kan word.

III

By Galileo vind ons die eerste en definitiewe breuk met die Middeleeuse metafisika. Die vraag is nou nie meer waarom? nie, maar hoe? Tog het daar nog heelwat reste van die Middeleeuse denkbeelde in sy gedagtestruktuur oorgebly. Ook sy opvolgers Descartes en Boyle het nog sterk onder invloed van die skolastieke metafisika gestaan. Newton was die man wat hom bewus daarop toegelê het om die natuurwetenskap 'n eksakte wetenskap te maak waar hipoteses en aprioris uitgeban is en slegs rekening gehou word met sintuiglik-uaarneembare verskynsels en die gevolge van eksperimentele navorsing.

Tog kon ook Newton nie ontkom aan die „metafisiese be hoefte" van die mens nie (Schopenhauer). Wie bewus alle metafisika uit sy stelsel wil uitban, bly nog onbewus onderhewig aan metafisiese denkbeelde. En die skerpsinnigste denker, ook al is hy positivisties in sy wetenskaplike arbeid, vind eers intellektuele bevrediging wanneer hy ook begin nadink oor die finale grond van die dinge.

Metafisiese denkbeelde by Newton is verskillend in aard. Daar is bv. begrippe wat eie was aan sy tyd en wat hy kritiekloos oorgeneem het. Algaande het Newton sy eie wetenskaplike metode tot metafisika verhef. Met ander woorde, hy het eenvoudig veronderstel dat die werklikheid sodanig is as wat die suksesvolle aanwending van sy metode vereis het. En eindelik het sy godsdienstige geloof hom verplig om na te dink oor die verhouding van God tot die wêreld.

Begrippe wat eie was aan sy tyd en wat Newton kritiekloos oorgeneem het, is o.a. die beskouing oor die verhouding tussen mens en wêreld. Ook vir Newton is die matematiese aspek die fudamentele eienskap van die stoflike wêreld. In laaste instansie bestaan die wêreld uit atome-in-beweging. Voorts vereenselwig hy ook die bewussyn met die siel en beskou hy die siel as 'n deel van die brein wat gelokaliseer kan word en wat hy die sensorium noem.

In sy verklaring van die wyse waarop dit moontlik vir die mens is om objekte waar te neem, gaan Newton eenvoudig terug na die teorie van Demokritos soos deur Descartes ont- 
wikkel. Klein stofdeeltjies of atome word van die waargenome objek gedra na die retina van die oog waar dit 'n afbeelding vorm. Hierdie afbeelding word deur trillinge van die oogsenuwees in die brein gedra en so sien 'n mens dan die objek van jou uaarneming (Opticks). Kleur is dan niks anders nie as 'n bepaalde geneigdheid (disposition) om bepaalde strale in groter oorvloed te weerkaats as ander; in die sensorium voel hierdie bewegings dan die kleure aan.

Dadelik vra 'n mens: maar hoe kan bewegings dan die gevoel van kleur veroorsaak? Eers antwoord Newton nie, maar later verklaar hy dat verskillende ligstrale trillinge van verskillende grootte (bignesses) veroorsaak. Die verskeidenheid in die grootte van die lig-trillinge veroorsaak die sensasie van verskillende kleure. Nog later was hy verplig om sy teorie verder te ontwikkel ten einde te verklaar hoe dit moontlik is vir 'n mens met twee oë om slegs die één waargenome objek te sien. Hy het dit so verduidelik dat die twee afbeeldinge op die twee retinas eers verenig word voordat dit die sensorium bereik.

Genoeg om aan te toon hoe kritiekloos Newton die metafisika van Descartes en Boyle oorgeneem het.

Maar, soos tevore reeds vasgestel, algaande het Newton sy eie wetenskaplike metode tot metafisika verhef. Dit blyk veral wanneer hy oor tyd en ruimte handel. Hier verlaat hy sy eie empiries-eksperimentele metode en neem hy sy uitgangspunt in sy eie wetenskaplike metode wat hy tot 'n onaantasbare dogma verhef. En uit hierdie dogma word dan verder afleidinge gemaak d.m.v. matematiese metodes. Uit die bestaan van die relatiewe tyd en ruimte wat sintuiglik-eksperimenteel bewys kan word, kom hy dan langs deduktiewe weg tot die bestaan van absolute tyd en ruimte.

Tot hierdie opvatting het Newton gekom as gevolg van sy godsdienstige en teologiese beskouinge. Teen die beswaar dat daar geen ruimte vir God is in 'n wêreld wat buite die mens 'n matematies-meganiese struktuur is nie, het Neu-ton in die tweede uitgawe van sy Principia (1713) geargumenteer dat God noodwendigerwys moet bestaan; sonder sy bestaan sal al die bestaande sinloos wees. Nou voer hy die begrip van absolute ruimte in. Absolute ruimte, aldus Newton, is die Goddelike sensorium; dit is nie alleen die Goddelike alomteenwoordigheid nie, maar ook die toneel van die Goddelike kennis en beheer oor al die geskapene. Die menslike sensorium, so 
gaan hy voort, veronderstel 'n Guddelike sensorium - die oneindige ruimte waarin God alles volmaak ken en volmaak doen en bcheer. En hieruit volg weer dat daar ook absolute tyd moet wees. In die absolute ruimte vervloei die absolute tyd gelykmatig sonder dat dit enige verband het met die uitwendige dinge.

So het Newton sy eie wetenskaplike metode tot metafisika verhef. Sonder enige bewyse wat op die grondslag van feite berus, het hy eenvoudig veronderstel dat die sigbare en die onsigbare werklikheid in ooreenstemming moet wees met die vereistes van sy wetenskaplike metode.

Maar ook 'n derde tipe metafisiese denkbeeld tref ons by Newton aan. Sy godsdienstige en teologiese oortuiginge het hom telkens gedwing tot besinning oor die dinge van die gees wat klaarblyklik in die gedrang kom by die konsekwente toepassing van sy stelsel. Altyd skaar hy hom aan die kant van manne soos Boyle en More wanneer hulle die stryd voer teen die anti-godsdienstige denkbeelde by Galileo, Descartes en Hobbes. Dit kom veral tot uiting in sy beskouinge oor twee sake, nl. die eter en God.

Wat eersgenoemde betref, erken Newton ruiterlik dat sy opvattinge blote hipoteses is. In 'n brief oor die onderwerp wat hy aan Boyle geskryf het, begin haas elke paragraaf met die woorde: „I suppose". Sy beskouinge hieroor is egter so onomlynd en hy skryf so aarselend daaroor, dat ons dit maar laat rus. Duideliker word sy insigte waar hy oor God handel.

God kan nie losgemaak word van die ondersoek van die fisiese natuur nie, aldus Newton. Inderdaad, elke suiwer vooruitgang in ons kennis van die fisiese realiteit bring ons nader aan God as die finale oorsaak van die dinge. Die natuurwetenskaplike en die teoloog benader die saak slegs van verskillende kante en met verskillende metodes. Newton het feitlik net soveel teologiese werke geskryf as natuurwetenskaplike verhandelinge. Hy het God erken as die Almagtige Skepper van die wêreld. In sy beskouinge oor die voorsienigheid en onderhouding het hy die ortodokse standpunt verdedig teenoor die deïsme. Ook het hy die moontlikheid van wondere toegegee. Leibniz en Huygens het die spot probeer drywe met Newton se Godsleer, maar laasgenoemde het oortuigend en waardig gereageer.

Die werklike invloed van Newton se teologie op sy natuurwetenskap was egter minimaal. In die lyn van die voluntarisme 
word God alleen bygebring as die Mag wat deur sy wil die wêreldorde daargestel het en in stand hou en slegs in die geval van die eter soms ingryp om die natuur te vernuut. As sommige uit sy wet van swaartekrag aflei dat dit 'n eienskap is wat inherent aan die materie is, dan wys Newton hulle tereg met die vermaning dat God daardie krag daarin gelê het. Die sterrehemel stort nie ineen nie, omdat God die sterre op genoegsame afstand van mekaar geplaas het, ens.

Dit is duidelik dat Newton se teologiese en godsdienstige gevoelens niks meer is as vreemde toevoegsels aan sy wetenskaplike sisteem nie. Sy nakomelinge het dit eenvoudig afgeskaf en Newton se insigte verder ontwikkel sonder om notisie te neem van sy teologiese denkbeelde. Aan sy oorspronklike insigte is also in ieder geval ook geen skade berokken nie.

Grondfout van Newton was natuurlik sy vooronderstelling waarop sy hele wetenskaplike metode berus, nl. dat godsdiens en wetenskap nooit bots nie en wel omdat hulle mekaar nooit ontmoet nie. Inderdaad vervul God in sy sisteem geen ander rol as dié van deus ex machina nie; Hy word alleen bygebring, gerieflikheidshalwe, om Newton uit 'n lastige parket te help.

Christelike wetenskap kan alleen groei uit die wortel van die Christelike wysbegeerte wat berus op die Skriftuurlike grondmotief van skepping, sondeval en verlossing deur Jesus Christus, in die gemeenskap van die Heilige Gees. Newton het geen oog gehad vir die noodsaaklikheid van hierdie voorvereiste nie. En so het dit gekom dat hy, 'n vrome en opregte Christen, die grondlegger geword het van die gesekulariseerde natuurwetenskap wat vandag die kragtigste bondgenoot geword het van die antichristelike magte in die wêreld.

Bloemfontein.

E. A. Venter. 